\title{
THE STUDENT HEALTH SERVICES AT THE UNIVERSITY OF PRETORIA FROM 2000 TO 2005
}

\section{Prof DH van Papendorp}

MB ChB, PhD

Head: Department of Physiology, University of Pretoria

Corresponding author: dvanpape@medic.up.ac.za

\author{
Dr M Coetzee \\ $\mathrm{PhD}$ \\ Lecturer, Department of Physiology, University of Pretoria
}

\section{Ms AM Koorts \\ MSc \\ Principal Technical Assistant, Department of Physiology, University of Pretoria}

Keywords: Student Health Services; University of Pretoria

\begin{abstract}
The University of Pretoria's Student Health Services provides free, voluntary, family-medicine-orientated health services with an emphasis on offering preventative medicine and health education to enrolled students. Students are examined and/or educated by skilled personnel familiar with the University's environment and demands. Apart from the family medicine services, the Student Health Services also educates students concerning contraception and sexually-transmitted diseases, carries out HIVIAIDS counselling and provides a comprehensive dietetic service. During the period 2000 to 2005 the percentage of students visiting the Student Health Services, of the total number of students enrolled at the University, remained almost constant at $12.5 \%$. A large percentage of the students making use of these services do belong to a medical aid and it is estimated that during the past six years the University of Pretoria has subsidised an amount of about R2.4 million towards the medical costs of students belonging to a medical aid.
\end{abstract}

\section{ABSTRAK}

Die Universiteit van Pretoria se Gesondheidsdienste voorsien gratis, vrywillige gesins-medisyne-georiënteerde gesondheidsdienste met die klem op voorkomende medisyne en gesondheidsopvoeding aan ingeskrewe studente. Studente word ondersoek en/of ingelig deur gekwalifiseerde personeel wat die Universiteit se omgewing en vereistes ken. Buiten die genoemde gesondheidsdienste lewer die Studente Gesondheidsdienste ook onderrig rakende voorbehoeding en seksueel-oordraagbare siektes, verskaf MIVIVIGS-berading en voorsien 'n omvattende dieetkundige diens. Gedurende die periode 2000 tot 2005 het die persentasie studente wat die Studente Gesondheidsdienste besoek het, van die totale getal ingeskrewe studente, naastenby konstant gebly op 12.5\%. 'n Groot persentasie van studente wat van die dienste gebruik maak behoort aan ' $n$ mediese fonds en dit is bereken dat die Universiteit van Pretoria gedurende die laaste ses jaar ongeveer R2.4 miljoen gesubsidieer het tot mediese onkostes van studente wat aan ' $n$ mediese fonds behoort. 
All South African Universities and tertiary education centres provide health services to their enrolled students. Annually, a national conference is held by the South African Association of Campus Health Services where presentations are given and common problems are discussed. The whole idea is to resolve problems and to compare similar issues to offer a better service. The aim of this report was to provide statistics from the Student Health Services of the University of Pretoria for discussion and comparative purposes.

The Student Health Services at the University of Pretoria is a facility that provides enrolled students with proper medical care. During their university career students may experience diverse physical and psychological health problems. Consequently it is the mission of the Student Health Services to offer free, voluntary, familymedicine-orientated health services, with an emphasis on preventative medicine and health education, to these students. Students are examined and/or educated by skilled personnel familiar with the university's environment and the demands that might be faced by the students.

\section{HISTORY OF THE STUDENT HEALTH SERVICES}

The Student Health Services at the University of Pretoria opened its doors for the first time on the $1^{\text {st }}$ of February 1974. At that time these services functioned as part of the newly established Department of Family Medicine in the Medical Faculty of the University, headed by the late Dr Howard Botha. He acted as the Chief Medical Officer of these services and was assisted by a fulltime professional nurse and two medical doctors. This arrangement, however, proved to be impractical and after 1976 the Student Health Services functioned independently but formed part of the Student Service Bureau. Utilisation of the service has steadily grown over the years, necessitating an increase in staff and the range of services. A permanent full-time medical doctor and additional part-time doctors working on a session basis were appointed in 1981. From 1999, on the retirement of its full-time head at the time, the Student Health Services no longer constituted part of the Student Service Bureau but functioned as part of the Student Support Services, headed by the Dean of Student Affairs. The Student Health Services are now managed by an administrative professional primary health worker, three full-time professional primary health workers and eight doctors who examine students part-time on a session basis.

\section{LOGISTICS OF THE STUDENT HEALTH SERVICES}

These services are housed in the historical Animal Sciences building on the main campus of the University, which was renovated in 1974 for use by the Students Health Services and included a waiting room, two consultation rooms, a recovery room and reception facilities. Since then the building has been altered twice and now boasts a more functional reception area/ waiting room and office space, as well as three consultation rooms, a recovery room and two counselling rooms. Further alterations are presently being planned so as to offer more consultation rooms. The service has also been expanded to other campuses, and student health services have been rendered at the Onderstepoort campus from 1989, the Medical campus from 2004 and the Groenkloof and Mamelodi campuses from 2005. The Student Health Services also rendered an emergency medical service at the sports fields during rugby matches for a number of years, until the management of sports injuries and rehabilitation was taken over by the Department of Sports Medicine of the Faculty of Health Sciences.

\section{NUMBER OF STUDENTSICONSUL- TATIONS AT THE STUDENT HEALTH SERVICES}

The total number of students who made use of these services increased from 3466 to 4754 in the years from 2000 to 2005 . However, the percentage of students visiting the Student Health Services, of the total number of students enrolled at the University, remained almost constant at $12,5 \%$ during this period. The number of female students who made use of these services was in these years almost twice that of the male students. However, once again the percentage of female/male students, of the total number of students making use of these services, remained fairly constant: $62 \%$ female and $38 \%$ male. The percentage of females in the total students enrolled was $52 \%$ while males represented $48 \%$.

The number of consultations offered is approximately 
double that of the number of students visiting the Student Health Services. Figure 1 illustrates the number of students visiting these services versus the number of consultations for 2000 to 2005 . The number of consultations is more or less double the number of students as a result of their follow-up visits. The total number of consultations increased from 5968 in 1976 to 9067 in 1986, reached 8526 in 2000 and was 9564 in 2005.

\section{DISEASE PROFILE OF STUDENTS VISITING THE STUDENT HEALTH SERVICES}

Students present with various symptoms in any of the following categories: respiratory system diseases, gastrointestinal system diseases, urogenital diseases, skin diseases and conditions, musculoskeletal diseases, eye and ear diseases and symptoms, cardiovascular diseases, mental derangements and injuries. Figure 2 depicts the categories of diseases and the number of students within each category from 2000 to 2005. Diseases involving the respiratory system are the most common amongst the students visiting the Student Health Services, with diseases of the cardiovascular system being the least frequent. The most common complaints related to the respiratory system are a variety of upper respiratory tract infections, while amongst gastrointestinal system diseases gastroenteritis is the most frequent; and for the urogenital system diseases it is cystitis.

Although mental derangements comprise a relatively small percentage of the different health conditions suffered by students who consult at the Student Health Services, their university careers can be jeopardised by psychological and emotional problems. Those who are very anxious and stressed, because of either academic, financial, personal, domestic or relationship issues, are counselled by either the doctor in charge or the clinical psychologist, and if necessary referred to a psychiatrist.

Substantial numbers of students are sexually active. The services therefore provide students with education on contraception and sexually-transmitted diseases. A

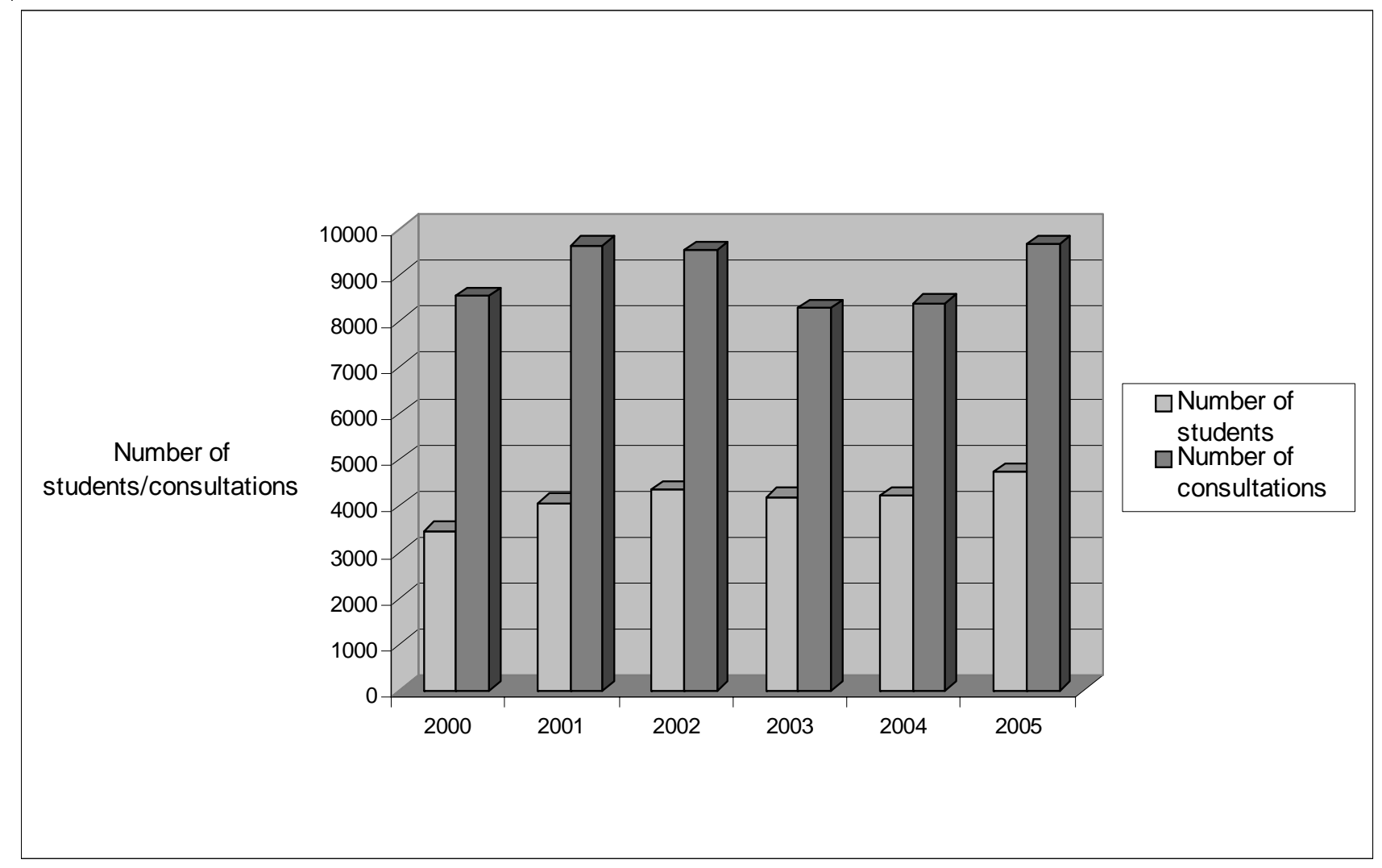

Figure 1: Number of students that visited the Student Health Services versus the number of consultations for the years 2000 to 2005 


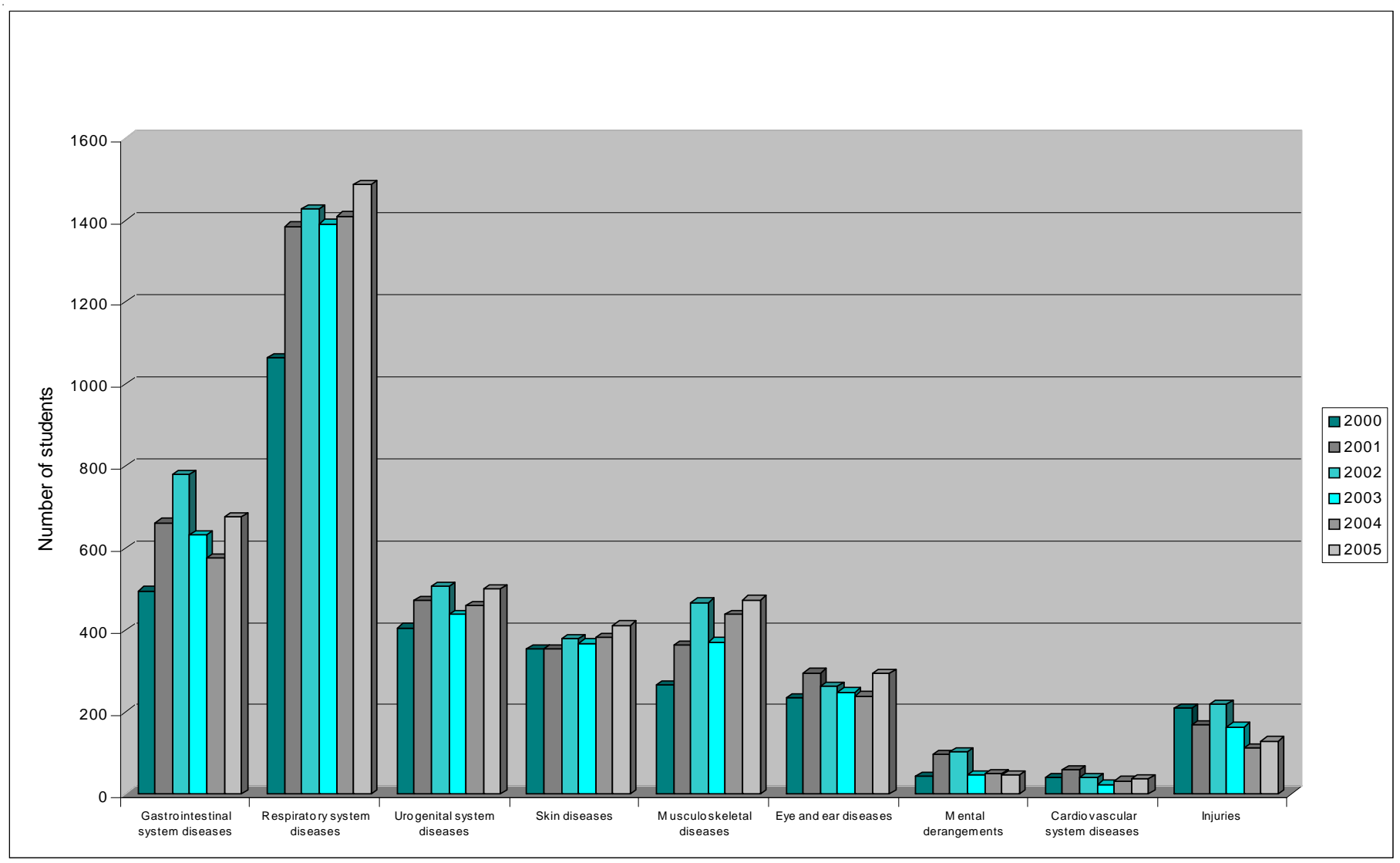

Figure 2: Number of students and categories of diseases for the years 2000 to 2005

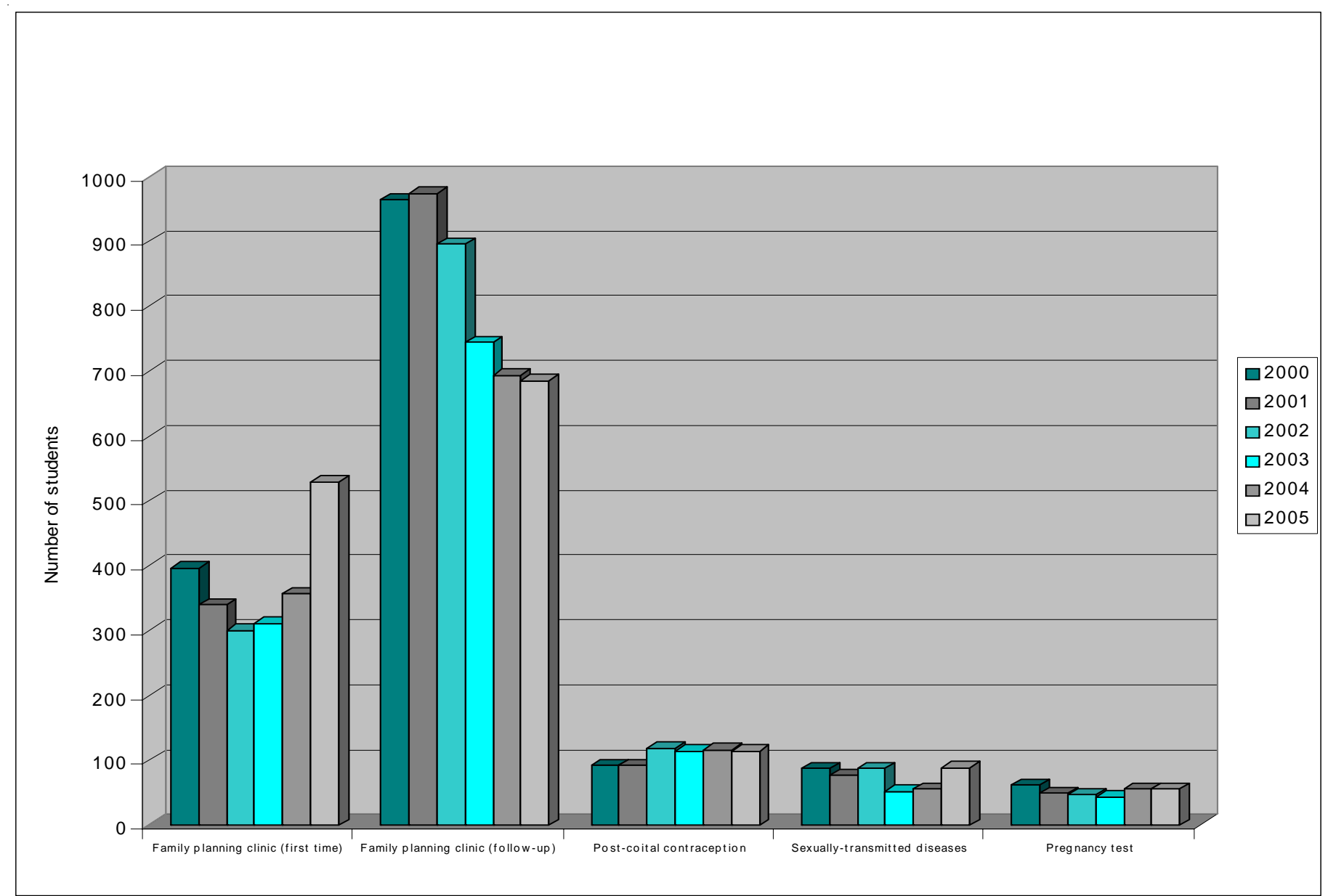

Figure 3: Number of students with sexually related medical consultations 
family planning clinic has been set up for this purpose. During 2000 to 2005 a total of 2231 students have made use of this facility. Any form of contraception is free of charge and is subsidised by the Department of Health. In this same time frame 645 students were seen for post-coital contraception. Although one would expect students to be well-aware of sexually-transmitted diseases, 446 students with such conditions were seen during 2000 to 2005 . From 2000 to 2005 , the result of 184 students of the 309 students tested for pregnancy, were positive. Figure 3 indicates the number of students visiting the family planning clinic for the first time, for follow-up visits, for post-coital contraception, sexuallytransmitted diseases and for pregnancy tests from 2000 to 2005. Table 1 and Figure 4 show the percentage of students per race group who presented with sexuallytransmitted diseases in this period. From Figure 4 it is clear that black and coloured female students comprise the biggest group of students seeking help for sexually-transmitted diseases, while white male and female students constitute the smallest group. Table 2 illustrates the numbers of students visiting the Student Health Services for a pregnancy test, and of those found to be pregnant. A few male students visited the Student Health Services for a pregnancy test - their female partners possibly being too embarrassed to make the visit.

It must be stated that owing to the sensitivity of these issues and being concerned that the results of confidential consultations might leak out, numerous students turn to private general practitioners in the Hatfield area for treatment of sexually-transmitted diseases.

\section{HIV and AIDS counselling service}

The Student Health Services furthermore hosts a HIV and AIDS counselling service, which consists of the professional primary health worker in charge and a few trained students from the Department of Psychology acting as counsellors. Students who do not know their HIV status can make use of this service. No HIV test is performed without prior counselling - this procedure is followed in order to prepare the student psychologically for a possible positive HIV test. Before the start of any counselling sessions a consent form has to be signed by the student to give permission for HIV testing. When a student has been properly counselled, a rapid HIV test (taking five minutes) is carried out by the professional primary health worker in charge. After a positive test further counselling sessions are arranged. Students are advised on specific lifestyle changes that need to be made and various follow-up tests that need to be performed. In 2005 a total of 624 students were tested and 11 were found HIV positive. In 2006 a total of 1604 students were tested and 10 were found HIV positive.

\section{Dietetic service}

The Student Health Services also hosts a comprehensive dietetic service, which is provided by $3^{\text {rd }}$ and $4^{\text {th }}$ year dietician students under the supervision of a registered dietician at the University of Pretoria. Students are first evaluated: information is obtained regarding their

Table 1: Percentage of students - of total students enrolled in category - with sexually-transmitted diseases

\begin{tabular}{l|cccccc} 
& 2000 & 2001 & 2002 & 2003 & 2004 & 2005 \\
\hline Male/Caucasian & 0.04 & 0.03 & 0.04 & 0.07 & 0.02 & 0.07 \\
Male/Black & 0.1 & 0.7 & 0.6 & 0.3 & 0.2 & 0.3 \\
Male/Asian & 1.9 & 0 & 0 & 0 & 0 & 0.1 \\
Male/Coloured & 1.5 & 0 & 0 & 0.4 & 0 & 0 \\
Female/Caucasian & 0.04 & 0.009 & 0.06 & 0.03 & 0.03 & 0.1 \\
Female/Black & 1.3 & 1.3 & 1.2 & 0.5 & 0.5 & 0.8 \\
Female/Asian & 0 & 0.2 & 0.1 & 0 & 0.2 & 0.1 \\
Female/Coloured & 0 & 0 & 1.2 & 0.8 & 0 & 0.3
\end{tabular}


current eating-habits and lifestyle and various anthropometric measurements are taken (weight, length, skin folds and circumferences). After a complete problem analysis and determination of dietary requirements, a plan of action and its implementation are put in place. Students are requested to make follow-up visits once or twice a week so that their progress can be monitored.

Students with any diet-related concerns use this service. These include:

- Weight loss

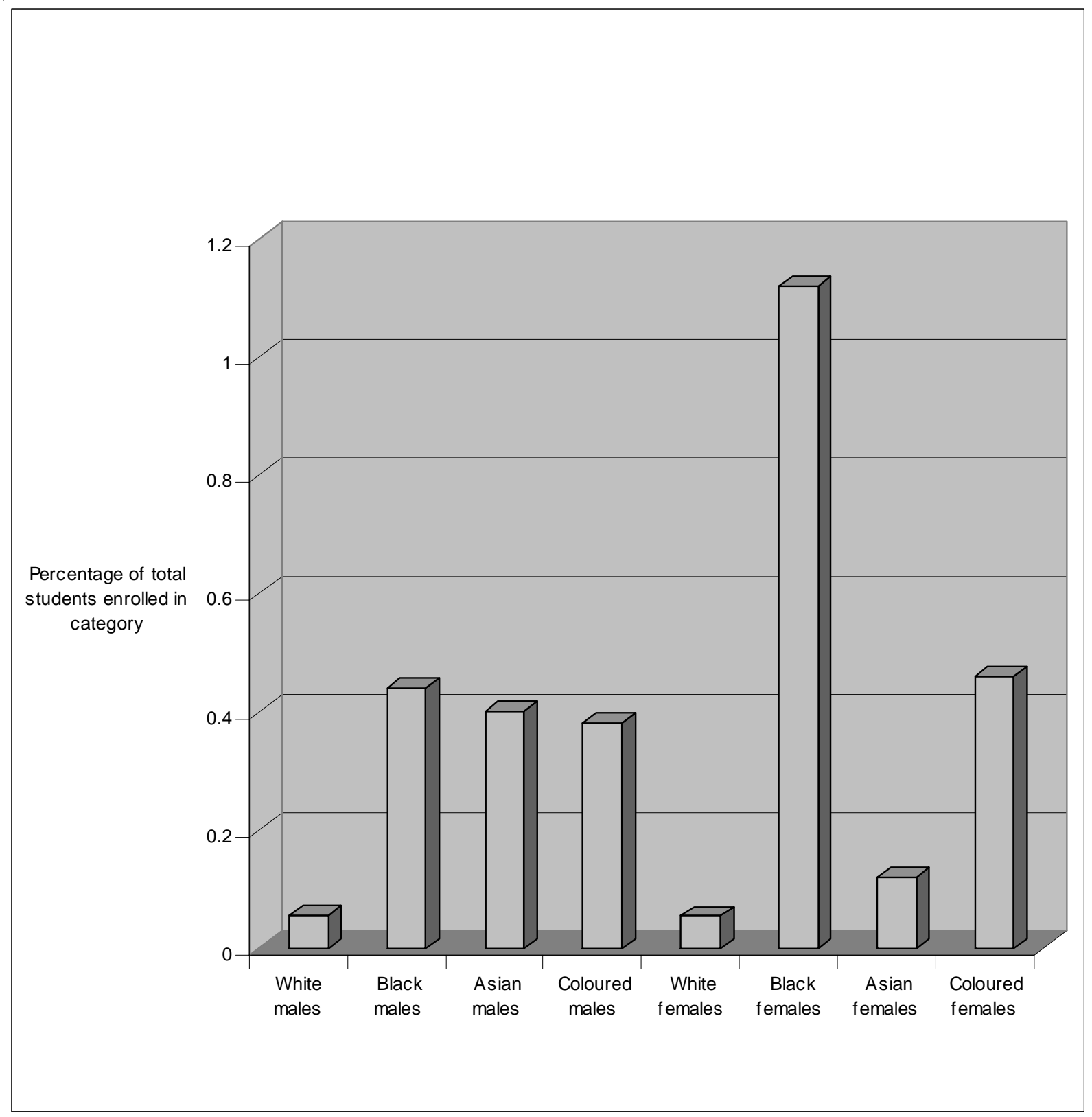

Figure 4: Percentage of students - of total enrolled category - with sexually-transmitted diseases

Table 2: Number of students visiting for a pregnancy test and number of students found pregnant

\begin{tabular}{l|rrrrrr} 
& 2000 & 2001 & 2002 & 2003 & 2004 & 2005 \\
\hline Pregnancy test & 61 & 49 & 46 & 43 & 55 & 55 \\
Pregnancy test positive & 40 & 27 & 45 & 20 & 28 & 24
\end{tabular}




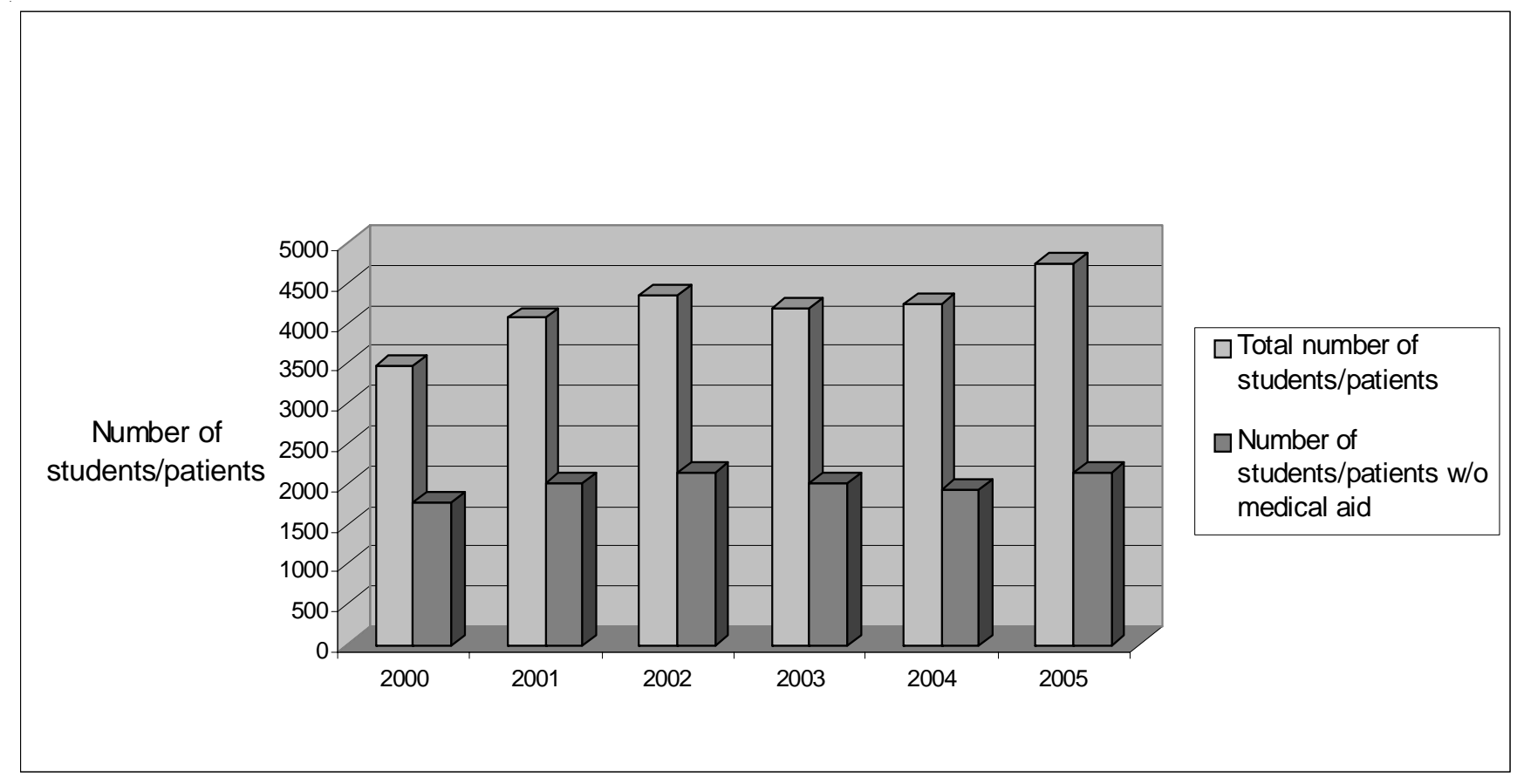

Figure 5: Total number of students/patients versus students/patients without a medical aid

- Weight gain

- $\quad$ Specific sport diets

- Therapeutic diet-related concerns such as low blood sugar, diabetes, allergies, constipation, irritable bowel syndrome, blood pressure problems, decreased immunity, etc.

\section{The Student Health Services at the Medi- cal and Onderstepoort campuses}

Students at the Medical and Onderstepoort campuses are perceived as a high-risk group for contagious diseases and are therefore immunised against Tuberculosis, Hepatitis, Rabies, etc. On these campuses the clinic service is unique in the sense that medical and veterinary students often insist on being referred for specialist medical care. It takes diplomatic persuasiveness to convince them that their condition is not always cancerous or as serious as they believe.

\section{SUBSIDISING OF THE STUDENT HEALTH SERVICES}

Where medication is prescribed it is for the student's own account. Depending on whether students belong to a medical aid scheme or not, they are referred, if necessary, to either private specialists or the Pretoria Academic Hospital. A large percentage of students do not have a medical aid. Figure 5 shows the total num- ber of students versus the number of students without a medical aid who visited the service during the period from 2000 to 2005. The Student Health Services provides free medical services to students. During 2000 to 2005 a total of 13076 medical consultations were provided to students with medical aids. The cost of visiting a general practitioner is approximately R180-00/consultation - it can therefore be estimated that the University of Pretoria provided a subsidy of R2.4 million towards the medical consultations of students belonging to a medical aid.

\section{CONCLUSION}

The University of Pretoria's mission is to provide students with proper teaching, to perform research, to deliver a service and to lay the foundation for the students to grow into mature professionals. The Student Health Services plays a vital role in fulfilling this mission, which is not only supported by consultations in the surgery but also by means of public lectures, information brochures and the encouragement of healthy relaxation, with the emphasis on high ethical and moral values. 